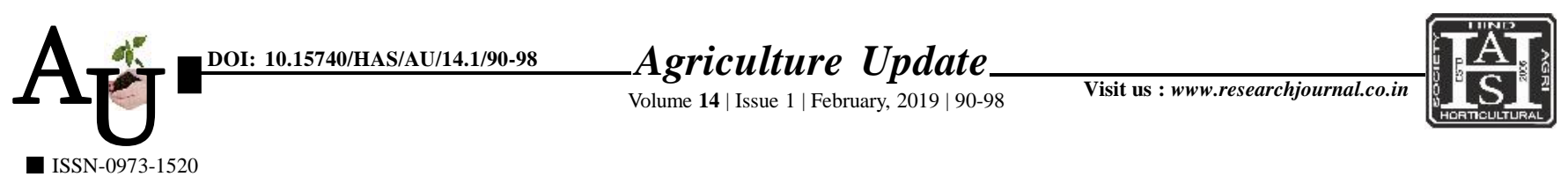

\title{
A CAsE Stuvy: Agricultural research and development in the developing world : Too little, too late?
}

\section{Upasana Mohapatra, Veeresh S. Wali, Swetalina Mohapatra and Vinoda Shankara Naik}

Article Chronicle: Received : 30.12.2018; Accepted : 30.01.2019

KEY WoRDS : Agriculture, Education, Technology, Research

Author for correspondence :

Veeresh S. Wali Department of Agricultural Economics, Orissa University of Agriculture and Technology, Bhubaneswar (Odisha) India

Email: waliveeresh92@ gmail.com

See end of the article for authors' affiliations

SUMMARY : The developing world faces the tough task of producing adequate food to meet the demands of its burgeoning population, as yield levels of major crops have struck a plateau. Food and nutrition security being the major concerns, agricultural $\mathrm{R}$ and $\mathrm{D}$ in less-developed countries is at the crossroads. The most significant demographic characteristic is that "virtually all population growth will occur in the poorer parts of the world'. The increasing population besides exerting pressure on food demand has also been striving to boost production and bring about balance in the demand-supply chain. Both rich and poor countries depend on the agricultural research conducted in the private and public laboratories of these countries. Those among the developing economies which strove to put their domestic agricultural $\mathrm{R}$ and $\mathrm{D}$ base into a state of preparedness for acclimatizing and absorbing the 'imported technology' on the one hand and to put the needed market and institutional arrangements in place on the other, emerged as the primary drivers of the adoption of new technologies. The need of the hour is to assess the ground reality is that whether agricultural R and D in the Third World countries is 'too little or too late'. The top five countries in terms of agricultural R and D spending are the United States, Japan, China, India, and Brazil. The government sector is still the main player in public agricultural $\mathrm{R}$ and $\mathrm{D}$, in terms of execution as well as funding. Although government allocations still present the main source of funding, there are again considerable differences across countries. A number of developing countries depend on non-governmental sources of funding. The majority of international agricultural $\mathrm{R}$ and $\mathrm{D}$ is carried out by the 15 research centers of the Consultative Group on International Agricultural Research (CGIAR). India has one of the largest and most complex agricultural research systems in the world, with more than a century of organized application of science to agriculture. The loss of dynamism in the agriculture sector is the major cause of crisis in Indian agriculture. Research and development $(\mathrm{R}$ and $\mathrm{D}$ ) has potential to offer long-term solutions to the problems of agriculture sector.In India, the public sector plays a major role in agricultural R and D. In the twelfth five year plan, the Indian Government addressed this deficiency by committing a significant percentage of AgGDP to agricultural R and D. ICAR and the SAU system are making a concentrated effort to better target research and to improve co-ordination of programmes across the various institutions. Food and nutrition security being the major concerns, agricultural $\mathrm{R}$ and $\mathrm{D}$ in less-developed countries is at the crossroads. Intensity of ARD in the developing nations is too little. But, it's never too late. Technology gap between developed and developing countries is increasing both, qualitatively and quantitatively.

How to cite this article : Mohapatra, Upasana, Wali, Veeresh S., Mohapatra, Swetalina and Naik, Vinoda Shankara (2019). Agricultural research and development in the developing world : Too little, too late?. Agric. Update, 14(1): 90-98; DOI : 10.15740/HAS/AU/14.1/90-98. Copyright@ 2019: Hind Agri-Horticultural Society. 